\title{
Pseudomembranous conjunctivitis: unveil the curtain
}

\author{
Pranita Sahay, Sridevi Nair, Prafulla Kumar Maharana, Namrata Sharma
}

Dr. Rajendra Prasad Centre for Ophthalmic Sciences, All India Institute of Medical Sciences, New Delhi, Delhi, India

\section{Correspondence to} Dr Prafulla Kumar Maharana, drpraful13@gmail.com

Accepted 27 February 2019

\section{DESCRIPTION}

Pseudomembranous conjunctivitis is an inflammatory condition of the conjunctiva characterised by mucopurulent discharge and pseudomembrane formation. A pseudomembrane is a thin yellowish-white membrane seen in the fornixes and palpebral conjunctiva that can be easily peeled off leaving an intact underlying epithelium. ${ }^{1}$ Corynebacterium diphtheriae, Neisseria gonorrhoeae, Streptococcus pyogenes and adenovirus are the commonly isolated micro-organisms in such cases. ${ }^{23}$ It is also seen in cases of acute Stevens-Johnson syndrome and ligneous conjunctivitis.

In our case, an 8-year-old girl presented with redness and watering in the right eye for 3 days. The visual acuity was hand motion and $6 / 6$ in the right and left eye, respectively. Purulent discharge, conjunctival congestion with membrane formation was noted in the right eye (figure 1). The left eye was normal. A sloughing corneal ulcer was suspected and the treatment was started with hourly instillation of topical gatifloxacin $0.5 \%$ and tobramycin $1.3 \%$ along with topical homatropine four times a day. A conjunctival swab was taken and sent for microbiological evaluation. Marked decrease in purulent discharge with organisation of the conjunctival membranes was noted after 2 days of initiation of treatment (figure 2). S. pyogenes was isolated from the conjunctival swab specimen. The conjunctival membrane was peeled off under direct visualisation of the slit lamp. The frequency of topical antibiotic was reduced and lubricating eye drop was started. At 1-week follow-up, complete resolution of inflammation was noted with a visual acuity of $6 / 6$ (figure 3 ).

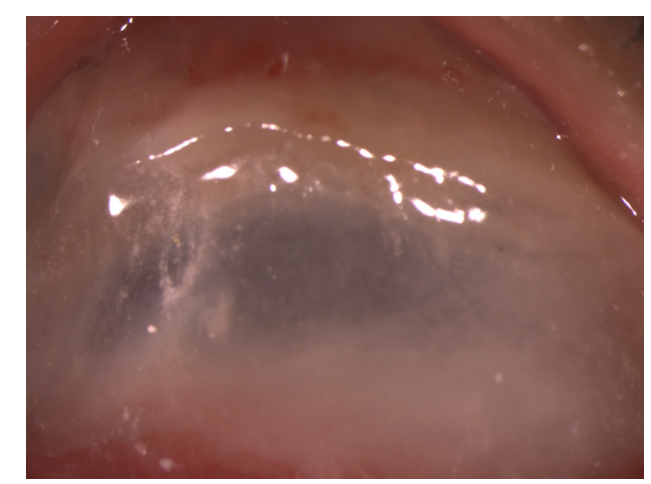

Figure 1 Slit lamp image of the right eye at presentation showing purulent discharge with membrane formation and suspicion of underlying sloughing corneal ulcer.

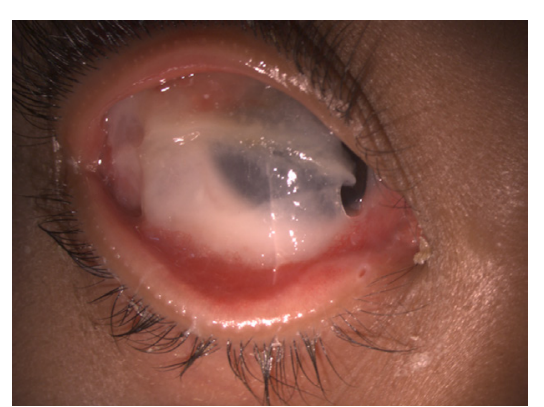

Figure 2 Slit lamp image of the right eye after 48 hours of initiation of antibiotic therapy showing an organised conjunctival membrane with normal anterior segment.

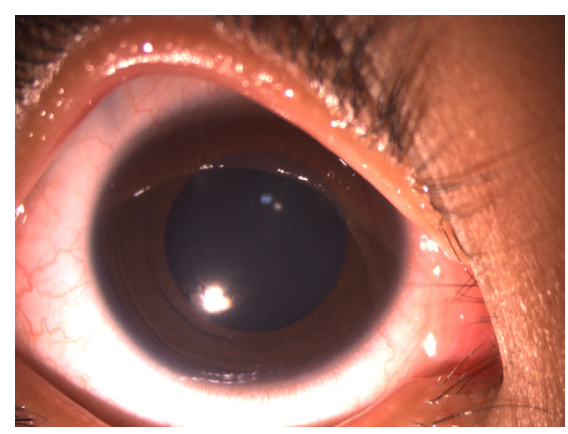

Figure 3 Slit lamp image of the right eye after 1 week of membrane peeling.

\section{Learning points}

Pseudomembranous conjunctivitis in severe cases may mimic sloughing corneal ulcer.

- Streptococcus pyogenes can be associated with pseudomembranous conjunctivitis.

Contributors PS has contributed to the concept, design and writing of the manuscript. SN has contributed in the acquisition of data and images. PKM has contributed to the concept, design and writing of the manuscript. NS has contributed to the writing and final editing of the manuscript.

Funding The authors have not declared a specific grant for this research from any funding agency in the public, commercial or not-for-profit sectors.

Competing interests None declared.

Patient consent for publication Parental/guardian consent obtained.

Provenance and peer review Not commissioned; externally peer reviewed.

\section{REFERENCES}

1 De Cock R. Membranous, pseudomembranous and ligneous conjunctivitis. Dev Ophthalmol 1997;28:32-45.

2 Kluever HC. Streptococcal pseudomembranous conjunctivitis: report of a case. American Journal of Ophthalmology 1935;18:1094-109.

3 Pihos AM. Epidemic keratoconjunctivitis: a review of current concepts in management. J Optom 2013;6:69-74. 
Copyright 2019 BMJ Publishing Group. All rights reserved. For permission to reuse any of this content visit https://www.bmj.com/company/products-services/rights-and-licensing/permissions/

BMJ Case Report Fellows may re-use this article for personal use and teaching without any further permission.

Become a Fellow of BMJ Case Reports today and you can:

- Submit as many cases as you like

- Enjoy fast sympathetic peer review and rapid publication of accepted articles

Access all the published articles

- Re-use any of the published material for personal use and teaching without further permission

For information on Institutional Fellowships contact consortiasales@bmjgroup.com

Visit casereports.bmj.com for more articles like this and to become a Fellow 